\title{
SCENARIOS TO COLLABORATE WITH EMERGING MARKETS: INITIAL FOCUS INDIA
}

\author{
*Myrna Flores, **Mathew Cherian, ***Luca Canetta \\ Swiss MTO Network - Swiss Federal Institute of Technology, Lausanne (EPFL) ${ }^{l}$ \\ myrflores@hotmail.com \\ **Indian Institute of Technology Madras, Department of Management Studies \\ mathewch@lycos.com \\ ***University of Applied Sciences of Southern Switzerland (SUPSI) \\ Department of Technology and Innovation, Institute CIM for Sustainable Innovation (ICIMSI) \\ \& Swiss Federal Institute of Technology, Lausanne (EPFL) \\ luca.canetta@supsi.ch, SWITZERLAND

\begin{abstract}
Due to competitive pressures in the global business arena, multinational firms have started to migrate to low-cost sources of labour and materials, which are typically located in countries that also represent emerging market opportunities. In the recent years, SME's are also interested in doing business in emerging markets, which represents a bigger effort and risk for them as they have less resources and time to recognize possible ways to start new successful collaborations with these countries and surpass the obstacles that they may encounter when creating new collaborative environments. These collaborations not only imply business opportunities to reduce operative costs or introduce products to those markets, but also innovation opportunities with Universities and Research Centres. Therefore, the objective of this paper is to present different scenarios to support firms to define collaboration strategies to develop new business and innovation opportunities in emerging markets and identify potential risks supporting them to develop new successful partnerships in their current value chain. For each scenario, main potential benefits, risks and critical success factors have been identified.
\end{abstract}

\section{INTRODUCTION}

Friedman (2005) describes three key periods of the world's globalization process in his book The World is Flat. He states that "Globalisation 1.0" is the time when Christopher Columbus discovered the American continent including the imperialist time of European countries until the late 1800s. Later on, "Globalisation 2.0" is the process when multinational companies are born and start to extend on new markets supported by technological advances of transportation and communication tools up to 2000. Then, the current stage is "Globalisation 3.0" that he calls the "flat world" on the sense that individuals are connected to the internet and can do business where ever they want in a virtual way. In this sense, individuals are the ones that collaborate and innovate using an open innovation model applying technologies such as open source tools which in fact are an output of these collaborative developments. The result is a triple convergence of technology, individuals and organisations skilled enough to take advantage of these new collaborative platforms.

\footnotetext{
${ }^{1}$ Dr. Myrna Flores was a visiting researcher as part of the Swiss MTO Network in EPFL during 2007
} 
Inspired by Friedman, Fung et al. (2008) provide an insight of different business opportunities that may arise in this "flat world" and highlight the importance of Emerging Markets as the markets of the future. Several analysis and researches carried out internationally confirm the importance of these markets in the current business arena. For instance in 2003, Goldman Sachs point out in a landmark study that by the year 2050, the economies of Brazil, Russia, India and China (BRIC) are expected to collectively eclipse those of U.S, U.K., Japan, Germany, France and Italy. Only the US and Japan would be left among the richest six countries. To these original six countries, some have added other markets such as Mexico, South Africa, Eastern Europe and Turkey. This growth will create rapidly new customer demand and changing spending patterns, leading shifts in the demand for different types of products as these markets develop. Global companies, including the SME's, need to be involved or will miss opportunities to grow with these emerging economies.

These last facts seem very promising to attract companies in the western world to invest and think of emerging markets to target new economic growth. Consequently, several questions may arise; especially when firms have not done yet business with these fast growing countries and when it is difficult to identify which is the best possible way to interact with them. At this point, several research questions emerge:

1. Which different collaboration models or scenarios can be developed to facilitate western companies, both multinationals and SME's, to find business opportunities and be successful in emerging markets obtaining win-win results?

2. Besides the economic returns, how can companies in collaborative networks develop and offer products and services considering also social and economic impacts towards a sustainable innovation model?

Therefore, the goal of this paper is to present the seven scenarios that were developed and analysed during the research carried out by the SWISSMAIN project trying to answer these two previous research questions.

\section{THE SWISSMAIN PROJECT AND THE INDIAN PILOT}

The SWISSMAIN project is a research project funded by the Swiss Innovation Promotion Agency - CTI International. One key research interest of the industrial partners was to identify new possible business models that can enable them to identify business and collaboration opportunities in India. The two main industrial partners interested in the research, Maillefer and SAPAL-Bosch, highlighted that besides the potential economic benefits that their companies may encounter developing new business relationships with India, social and environmental elements also should be taken into consideration. Both companies are interested to identify potential collaboration opportunities to develop new long term relationships with Indian partners that also pay attention to sustainable development matters such as:

- Adoption of "green" practices at overall production equipment design, manufacturing, use and disposal

- Implementation of Environment, Health and Safety (EHS) procedures increasing the quality of life, working conditions, safety and health of their employees and of the production equipment users. 
Therefore, the concept of Sustainable Innovation was applied to develop the scenarios. Sustainable innovation is an emerging and fundamental force for change in business and society (Larson, 2000). Sustainable innovation is a process where sustainability considerations (environmental, social, financial) are integrated into company systems from idea generation through to research and development (R\&D) and commercialisation. This applies to products, services and technologies, as well as new business and organisation models (Charter et. al., 2007) According to Rennings (2000) sustainable innovation or eco-innovation is the process of developing new ideas, behaviour, products and processes that contribute to a reduction in environmental burdens or to achieve ecologically specified sustainability targets. As a result, the SWISSMAIN Indian pilot was launched with the objective to support Swiss and Indian companies in the machine building sector to identify collaboration opportunities considering sustainable innovation concepts (economic, social and environmental). One deliverable of this Indian Pilot was to develop scenarios to facilitate Swiss firms to identify different potential ways to do business in India which could evolve into new collaborative environments, where not only Swiss firms obtain sustainable benefits but also the Indian counterparts.

\section{RESEARCH METHODOLOGY: SCENARIO PLANNING}

Scenario Planning acknowledges that the future is unpredictable and takes that into account by providing a number of different versions of the future. In contrast, most of the other strategic planning tools attempt to predict only one version of the future. It is essential that scenarios are developed in a participative process, sharing perspectives and different points of view. This process in fact requires serious research in the form of data gathering and analysis. Additionally, resulting scenarios should evolve to time, they should be revisited at least annually (Turner, 2002).

According to Schoemaker (1995), scenario planning enables managers to identify a big range of possibilities to capture different opportunities in rich detail; Scenario Planning is a disciplined method to imagine different futures that can be applied to greater range of futures simplifying the avalanche of data into a limited number of possible states. Even though the proposed SWISSMAIN scenarios were defined targeting new collaborative environments for Indo-Swiss collaborations, they could also be applied within other contexts. The current state is the "AS-IS" scenario and applying the Scenario Planning research methodology seven different scenarios were developed after carrying out fifteen face to face interviews to companies both in India and Switzerland during the SWISSMAIN Indian pilot.

To identify, develop, compare and analyse the possible business scenarios among Swiss and Indian entrepreneurs, a questionnaire with both open and multiply choice questions was designed to carry out face to face interviews. This SWISSMAIN survey had as an objective to understand the current business arena from Swiss and Indian entrepreneurs considering their initial (past), current and future collaboration perspectives and integrating a Sustainable Development Framework (Flores, et al 2008). More specifically, the first part of the questionnaire focused on gathering data about: 1) the different reasons of Swiss companies doing business in India or vice versa, 2) the impact, 3) the main challenges and 4) the Critical Success Factors (CSF's). The second part had the objective to obtain information about the experiences of the Swiss 
companies doing business in India applying the three axes of sustainable development: economic, social and environmental.

The economic aspects were covered by collecting data about: production (type of products/components produced, market lifecycle phase, main activities, market focus); logistics (lead-time duration and reliability, transport modes, costs); market (potentiality and profitability, competitive degree), etc. The social aspects considered the cultural differences as well as workforce attitude, organisational behaviour, trust and loyalty. Looking more specifically to the adopted strategies the impact of training (contents, procedures, costs and effectiveness) and management styles (types of ownership, governance models, etc). The environmental axis looked forward to understand how Swiss and Indian companies were sharing green supply chain best practices and how Indian counterparts were adopting them. The role of local universities and research centres to spur innovation in India was also addressed.

\subsection{The "AS IS" scenario: Supply chain}

Supply Chain Management (SCM) is the total management of a network of facilities and distribution options in a partnership between a consumer, distributor and manufacturer with the purpose of transfer and exchange information and physical goods for the supplier's suppliers to their customer's customers ensuring the right goods in the most efficient manner, reached accurately wherever they are required in a company and beyond (SCOR, 1995).

Within the context of the project, Swiss companies are mainly sourcing components from European suppliers but exporting globally. There is currently no collaboration for product development with Indian partners, furthermore considering product innovation and market introduction in India, the presence of Swiss firms is still very low in contrast to German and Japanese competitors.

\subsection{Scenario 1: Expand sourcing and selling towards product customisation}

The very first scenario, in terms of lower collaboration complexity, targets an expansion of current sourcing and selling activities in India, considering (table 1):

- The Swiss company's production/assembly remains in Switzerland

- The Swiss firm assesses and selects new Indian suppliers, targeting a more collaborative environment for product design and customisation for India

- Starts business collaborations, mainly selling and buying transactions

- Swiss finished product(s) are sold to the same markets and/or new markets (including India)

In fact, Subramanian, (2007) found that Indian Manufacturing Enterprises, particularly SME's, have been benefited from the large-scale subcontracting of parts and components from Indian and overseas OEMs. 


\begin{tabular}{|c|c|}
\hline \multicolumn{2}{|l|}{ Win-Win Benefits } \\
\hline $\begin{array}{l}\text { For Swiss } \\
\text { - Outsource to reduce costs (exports of components) } \\
\text { Be more competitive thanks to cost reduction (cost } \\
\text { reduction strategy) } \\
\text { - Integrate new suppliers for collaborative design }\end{array}$ & $\begin{array}{l}\text { For Indian company } \\
\text { - Increase sales (exports) } \\
\text { - Learn procedures and quality standards } \\
\text { from Swiss company, especially in } \\
\text { regards to environmental procedures }\end{array}$ \\
\hline \multicolumn{2}{|l|}{ Risks } \\
\hline $\begin{array}{l}\text { For Swiss } \\
\text { - Increase complexity in Supply Chain in regards to } \\
\text { the quality specifications, Indian suppliers not } \\
\text { delivering on time. } \\
\text { - Loss of local skills in regards to the production } \\
\text { know-how of some components } \\
\text { - Communication and cultural difference before and } \\
\text { during the business transactions }\end{array}$ & $\begin{array}{l}\text { For Indian } \\
\text { - Not enough experience/knowledge to } \\
\text { supply what is requested } \\
\text { - Need to strongly invest in technology } \\
\text { and training due to the lack of } \\
\text { technological competencies which is } \\
\text { difficult especially for Indian SME's. }\end{array}$ \\
\hline \multicolumn{2}{|l|}{ Critical Success Factors (CSFs) } \\
\hline \multicolumn{2}{|c|}{$\begin{array}{l}\text { - Develop a robust suppliers selection methodology } \\
\text { - Select the right suppliers } \\
\text { - Implement clear procedures and methods for production and quality management } \\
\text { - Establish efficient communication channels } \\
\text { - Define a supply chain performance scorecard } \\
\text { - Collaboration increases with the usage of new Information and Communication Technologies } \\
\text { (ICT), especially Enterprise Resource Planning systems that focus on sharing operational } \\
\text { information } \\
\text { - Study the life cycle of the product and integrate new suppliers for collaborative design for product } \\
\text { customisation }\end{array}$} \\
\hline
\end{tabular}

Table 1. Expand Sourcing and Selling for Product Customisation

\subsection{Scenario 2: Concentrate sourcing in developed / developing industrial clusters}

The second identified scenario looks forward to motivate and enable Swiss firms to look for business opportunities by collaborating with Indian partners located in established or developing new clusters (table 2). An Industrial Cluster is defined as a concentration of 'interdependent' firms within the same or adjacent industrial sectors in a small geographical area (Observatory of European SME's, 2002). Porter (1990) defines a cluster as a set of industries related through buyer-supplier and supplier-buyer relationships, or by common technologies, common buyers or distribution channels, or common labour pools. Clustering and networking has helped Indian small and medium enterprises in boosting their competitiveness. India has over 400 SME clusters and about 2000 artisan clusters. Therefore, in scenario 2 the following is considered:

- The Swiss company's production/assembly remains in Switzerland

- The Swiss company assesses and selects suppliers located in well established clusters (industrial aggregations) in different locations in India taking advantage of scale economies, networking activities and established infrastructure in the cluster (such a training from local associations and Universities).

- New long term Indo-Swiss partnerships are built focusing on new product development or re-design of products with local suppliers and customers 
- $\quad$ Swiss finished product(s) are sold to the same and new emerging markets

\begin{tabular}{|c|c|}
\hline \multicolumn{2}{|l|}{ Win-Win Benefits } \\
\hline $\begin{array}{l}\text { For Swiss } \\
\text { - Win-win attitude } \\
\text { - Develop a new collaborative environment to solve } \\
\text { targeted problems sharing information } \\
\text { - Improve interface with suppliers in the same } \\
\text { cluster to improve overall product performance } \\
\text { (design and quality) } \\
\text { - Reduce costs to manage multiple suppliers within } \\
\text { the same cluster Multiplying effects by working } \\
\text { with different suppliers within the same location } \\
\text { - The Indian government is investing in the upgrade } \\
\text { and development of clusters, facilitating } \\
\text { companies to find the right partner, especially } \\
\text { SME's }\end{array}$ & $\begin{array}{l}\text { For Indian } \\
\text { - Win-win attitude } \\
\text { - Increase quality by learning from Swiss } \\
\text { procedures } \\
\text { - Faster learning process and product } \\
\text { improvement } \\
\text { - Economies of scale (share costs for } \\
\text { transportation, warehousing, trainings, etc) } \\
\text { - The collaboration of suppliers in the cluster } \\
\text { maximises the combined competencies of } \\
\text { partners to achieve each partner's production } \\
\text { order } \\
\text { - Faster access of Indian components to the } \\
\text { global market increasing their exports }\end{array}$ \\
\hline \multicolumn{2}{|l|}{ Risks } \\
\hline $\begin{array}{l}\text { For Swiss } \\
\text { - Not finding the right suppliers in the cluster } \\
\text { - Difficulty to orchestrate suppliers in the cluster } \\
\text { Possibility to loose property rights to competition } \\
\text { who also source to suppliers within the same } \\
\text { cluster } \\
\text { - Indian partners do not have the same IT tools for } \\
\text { long distance communication }\end{array}$ & $\begin{array}{l}\text { For Indian } \\
\text { - Usually the OEM orchestrates the New } \\
\text { Product Development (NPD) process, } \\
\text { SME's have very little decisional power } \\
\text { - Swiss partners do not have the same IT tools } \\
\text { for long distance communication } \\
\text { - Swiss partners do not speak English fluently } \\
\text { and existence of cultural differences }\end{array}$ \\
\hline \multicolumn{2}{|l|}{ Critical Success Factors (CSFs) } \\
\hline \multicolumn{2}{|c|}{$\begin{array}{l}\text { - Identify most advanced clusters in India following a process oriented strategy (potential clusters } \\
\text { Pune, Vadodara, Ludhiana for machined parts and components) } \\
\text { - Develop a suppliers' selection methodology } \\
\text { - Diffuse and implement easy to use information and communication tools (ICT) for information } \\
\text { sharing and suppliers management } \\
\text { - Co-development of products including customer's and supplier's know-how for local product } \\
\text { customisation }\end{array}$} \\
\hline
\end{tabular}

Table 2. Concentrate Sourcing in Developed/Developing Clusters identified benefits, risks and Critical Success Factors (CSF).

\subsection{Scenario 3: Develop new cross boarder alliances}

A Cross-border alliance can be defined as partnerships that are formed between two or more firms from different countries for the purpose of pursuing mutual interests through sharing their resources and capabilities (Doz et al., 1998). According to Dyer et al. (2001), cross-border alliances (CBAs) aim in bringing in superior competitive position to involved firms. Lorange and Roos (1992) broadly classify strategic alliance as:

1. A formal cooperative venture of two or more independent firms formally working together for their mutual benefits

2. A joint venture to form a separate company of which the founding firms have equity stakes

3. A joint ownership of asset or economic activity to serve interests of partner firms 
4. A strategic investment in a partner or share swap as a gesture of working together or a precursor to a merger or to exploit formal ownership rights. Therefore, in this scenario 3:

- The Swiss company looks for an existing Indian partner in the same or related market for fast entry to the emerging Indian market

- The Indian and Swiss partner form a new company with a common strategy and vision

\begin{tabular}{|c|c|}
\hline \multicolumn{2}{|l|}{ Win-Win Benefits } \\
\hline $\begin{array}{l}\text { For Swiss } \\
\text { - Faster access to new market (India) taking } \\
\text { advantage of the Indian partner knowledge in } \\
\text { regards to customer requirements from the Indian } \\
\text { counterpart } \\
\text { - Lower risk in managing firm in unknown and } \\
\text { different business and cultural contexts } \\
\text { - Customize design identifying the voice of local } \\
\text { customers (VOC) } \\
\text { - Increase sales through local known distribution } \\
\text { channels and customer contacts }\end{array}$ & $\begin{array}{l}\text { For Indian } \\
\text { - Acquire new technology and learn best } \\
\text { practices from foreign (Swiss) firm } \\
\text { - Obtain new technical skills for higher } \\
\text { technological products } \\
\text { - Increase financial returns based on a product } \\
\text { differentiation strategy in domestic market } \\
\text { - Provide reduction of raw materials and } \\
\text { components costs with local procurement }\end{array}$ \\
\hline \multicolumn{2}{|l|}{ Risks } \\
\hline $\begin{array}{l}\text { For Swiss } \\
\text { - Loose Intellectual Property (IP) } \\
\text { - Strong cultural differences in doing business and } \\
\text { therefore possible emergence of conflicts } \\
\text { - Increase the complexity of the supply chain, } \\
\text { considering new suppliers and introducing the } \\
\text { need to implement new forecasting systems }\end{array}$ & $\begin{array}{l}\text { For Indian } \\
\text { - Been selected as a partner due to the low } \\
\text { cost of labour, thus low collaboration in the } \\
\text { new product development process with } \\
\text { Swiss partner is limited. Once the foreign } \\
\text { partner learns about the emerging market, } \\
\text { might want to finish the cross boarder } \\
\text { alliance. } \\
\text { - Needs to invest in R\&D to catch up } \\
\text { technologically. This is risky if the Indian } \\
\text { company usually doesn't to invest in R\&D }\end{array}$ \\
\hline \multicolumn{2}{|l|}{ Critical Success Factors (CSFs) } \\
\hline \multicolumn{2}{|c|}{$\begin{array}{l}\text { - The right alliance partner selection with clear and aligned long term business strategies } \\
\text { - Define and implement the right governance model, identifying the key skills required from both } \\
\text { partners to work together in common and new markets with current or customised products } \\
\text { - Jointly develop and agree on precise terms and conditions, especially Intellectual property rights } \\
\text { - Key processes to develop together as a new partnership integrating knowledge to be stronger at } \\
\text { marketing and product development }\end{array}$} \\
\hline
\end{tabular}

Table 3. Develop New Cross Boarder Alliances identified benefits, risks and Critical Success Factors (CSF).

\subsection{Scenario 4: Full ownership in emerging market}

In this full ownership scenario, the Swiss opens a new production facility in India targeting the local (Indian and/or emerging) market with existing products or customized ones according to the local needs. Based on the different interviews carried out in Swiss companies located in India, this was identified as the most common scenario of Swiss firms investing in India, as for many of them seems less risky due to the fact that business culture is very different and unknown to Swiss 
counterparts, especially SME's. The following table shows the identified win-win benefits, risks and identified CSF's.

\begin{tabular}{|c|c|}
\hline \multicolumn{2}{|l|}{ Win-Win Benefits } \\
\hline $\begin{array}{l}\text { For Swiss } \\
\text { - Full control and ownership to take decisions in } \\
\text { foreign location (India) } \\
\text { - Easier access to new market (India) } \\
\text { - Understand more closely the local market needs } \\
\text { - Reduce labour and logistic costs } \\
\text { - Consider to define and develop projects with } \\
\text { local Universities to identify qualified students } \\
\text { that can later become employees }\end{array}$ & $\begin{array}{l}\text { For Indian } \\
\text { - Swiss company will source from Indian } \\
\text { suppliers (SME's) integrating them to their } \\
\text { local supply chains } \\
\text { - Swiss company will provide new jobs and } \\
\text { training (when required) to Indian qualified } \\
\text { personnel } \\
\text { - Swiss Environment, Health and Safety (EHS) } \\
\text { practices will be implemented and diffused } \\
\text { by Swiss companies in India and its local } \\
\text { suppliers }\end{array}$ \\
\hline \multicolumn{2}{|l|}{ Risks } \\
\hline $\begin{array}{l}\text { For Swiss } \\
\text { - Failure due to lack of knowledge about market, } \\
\text { legal issues, business \& working culture } \\
\text { - Lack of qualified Indian workforce at the } \\
\text { technical and managerial level, therefore need to } \\
\text { bring expats to the foreign office } \\
\text { - High employee rotation, as many multinationals } \\
\text { look continuously for new training personnel in } \\
\text { India, which in some occasions is not enough to } \\
\text { cover the demand. } \\
\text { - Less understanding about Indian regulations }\end{array}$ & $\begin{array}{l}\text { For Indian } \\
\text { - Not been able to provide high-quality } \\
\text { components to Swiss company } \\
\text { - Not motivate Swiss companies to increase } \\
\text { investments due to bureaucracy, corruption } \\
\text { and lack of infrastructure }\end{array}$ \\
\hline \multicolumn{2}{|l|}{ Critical Success Factors (CSFs) } \\
\hline \multicolumn{2}{|c|}{$\begin{array}{l}\text { - Hire qualified Indian personnel with experience and skills for the different functions of the company } \\
\text { in India: marketing, product development, legislations, technical knowledge in regards to product } \\
\text { and process } \\
\text { - Create new market channels and customer contacts in India as soon as possible } \\
\text { - Select the right location in India closer to good sources of knowledge such as clients, suppliers and } \\
\text { Universities. Take into consideration where competitors, both domestic and foreign have establishec } \\
\text { their firms in India. Take also in consideration the infrastructure, such as airports, roads and ports. } \\
\text { - Take advantage of Special Economic Zones (SEZs) being developed by the Indian government to } \\
\text { pay less taxes } \\
\text { - In case there is no knowledge about local regulations, consider to hire a skilled consultant } \\
\text { - Analyse carefully the market needs and customise products according to local desires }\end{array}$} \\
\hline
\end{tabular}

Table 4. Full Ownership in India identified benefits, risks and Critical Success Factors (CSF).

\subsection{Scenario 5: Acquisition in emerging market}

In this scenario the Swiss company searches, selects and performs a due diligence to acquire a successful Indian-own established company in the same or similar industrial sector to facilitate the company entry to that (Indian and/or Asian) market with existing products or customized ones according to the local markets needs. This is not a very common practice done by Swiss companies, but in contrast there is an increasing trend from Indian successful firms in western countries, which nowadays are buying several successful companies around the world to expand their market horizons. Indian business investors have lately acquired western owned firms from 
different sectors including steel, pharmaceuticals, automotive components, televisions, such as the recent Jaguar acquisition of the TATA Group from Ford among others. The win-win benefits, risks and identified CSF's are presented in the following table.

\begin{tabular}{|c|c|}
\hline \multicolumn{2}{|l|}{ Win-Win Benefits } \\
\hline $\begin{array}{l}\text { For Swiss } \\
\text { - Full control and ownership to take decisions in } \\
\text { emerging market (India) } \\
\text { - Faster access to a new fast developing emerging } \\
\text { market } \\
\text { - Capitalise from acquired company knowledge in } \\
\text { market business intelligence, distribution } \\
\text { channels, suppliers base and customer contacts } \\
\text { for product customisation }\end{array}$ & $\begin{array}{l}\text { For Indian } \\
\text { - Attract foreign capital to India } \\
\text { - Merge Swiss competences about high tech } \\
\text { products with the knowledge of the Indian } \\
\text { acquired company in regards to the market and } \\
\text { distribution channels to provide more advanced } \\
\text { goods to the final consumers and increase the } \\
\text { market share. }\end{array}$ \\
\hline \multicolumn{2}{|l|}{ Risks } \\
\hline $\begin{array}{l}\text { - Swiss company is not getting profit of acquired } \\
\text { Indian acquisition in the expected period of time. } \\
\text { Return of investment (ROI) takes more time of } \\
\text { the expected } \\
\text { - The learning curve is to slow to manage the new } \\
\text { acquired company in the emerging market } \\
\text { - Not able to diffuse Swiss business culture and } \\
\text { procedures in new acquisition } \\
\text { - Difficulty to find enough skilled personnel } \\
\text { - Current supplier base is not providing the } \\
\text { expected quality. Investment will be required to } \\
\text { train key suppliers and search for new ones that } \\
\text { could supply the requested components } \\
\text { - Indian suppliers and employees need training to } \\
\text { use the IT systems used in Switzerland }\end{array}$ & $\begin{array}{l}\text { - Indian employees do not have the competences } \\
\text { needed by the Swiss company, so some of them } \\
\text { may be replaced by skilled employees, in some } \\
\text { cases coming from Switzerland } \\
\text { - Current supplier base is not providing the } \\
\text { expected quality. Some suppliers may be } \\
\text { replaced by European known suppliers }\end{array}$ \\
\hline \multicolumn{2}{|l|}{ Critical Success Factors (CSFs) } \\
\hline \multicolumn{2}{|c|}{$\begin{array}{l}\text { - Retain key personnel from acquired company } \\
\text { - Learn fast from Indian partner about distribution channels and the suppliers base } \\
\text { - Implement Swiss business strategy and procedures as soon as possible in the new acquisition } \\
\text { - Transfer quickly the best business practices to the new Indian acquisition } \\
\text { - Understand quickly the market requirements to supply a localised mass customisation strategy for } \\
\text { product development } \\
\text { - Do joint projects with local Universities to identify smart students to work later on in Swiss firm } \\
\text { - Join the local chamber of commerce to learn and understand the emerging market business environment } \\
\text { and make new contacts } \\
\text { - Visit and evaluate suppliers to understand which improvements could be done in the current supply } \\
\text { chain and define actions for improvement }\end{array}$} \\
\hline
\end{tabular}

Table 5. Acquisition in Emerging market identified benefits, risks and Critical Success Factors (CSF).

\subsection{Scenario 6: Technology transfer to firm in emerging market}

This sixth scenario considers a Swiss company licensing technology to an Indian firm to produce a finished product not existing in that particular emerging market. This is one of the most complex scenarios, as it is difficult for a company to select which technology to license to still keep its competitive advantage and access that particular market. Additionally, it required a very high level of trust from the Swiss 
partner to license the technology to a counterpart in the emerging market to follow all the terms and conditions established and agreed in the technology transfer deal.

For instance, one of the identified case studies under this scenario considered the technology transfer of a mature product which was the first step undertaken by one of the interviewed Swiss companies to establish its presence in India, then the adopted strategy evolved into a full ownership combined with partial local sourcing. The technology transfer scenario was also adopted by an Indian company which established a technological alliance with a South-African counterpart. In this second case study, the technology transfer process was successful and took place in three phases and lasted for seven years. This progressive transition allowed partners to increase their trust and to make affordable the technology transfer being a learning experience for both counterparts.

\begin{tabular}{|c|c|}
\hline \multicolumn{2}{|l|}{ Win-Win Benefits } \\
\hline $\begin{array}{l}\text { For Swiss } \\
\text { - Increase profits by selling technology licenses } \\
\text { to an Indian firm to introduce a new product to } \\
\text { the that particular market } \\
\text { - By learning from the experiences done by the } \\
\text { Indian firm to sell the products in the domestic } \\
\text { market, the Swiss firm can customise the } \\
\text { technology to the local needs }\end{array}$ & $\begin{array}{l}\text { For Indian } \\
\text { - Merge Swiss competences about high tech } \\
\text { products with Indian knowledge about the market } \\
\text { to provide more advanced goods for the final } \\
\text { consumers } \\
\text { - Product diversification thanks to the acquisition } \\
\text { of Swiss technology with a license } \\
\text { - Obtain training for local product manufacturing } \\
\text { providing Swiss quality specifications }\end{array}$ \\
\hline \multicolumn{2}{|r|}{ 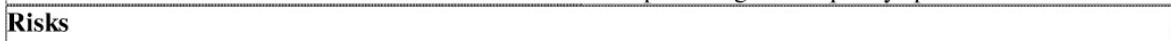 } \\
\hline $\begin{array}{l}\text { - Indian partner does not respect the license IPR } \\
\text { agreement } \\
\text { - Do not understand properly Indian laws and } \\
\text { regulations }\end{array}$ & $\begin{array}{l}\text { - Indian employees do not have the competences } \\
\text { needed by the Swiss company to sell the product } \\
\text { in India. Therefore, Indian firm is not selling to } \\
\text { the market the right product. }\end{array}$ \\
\hline \multicolumn{2}{|l|}{ Critical Success Factors (CSFs) } \\
\hline \multicolumn{2}{|c|}{$\begin{array}{l}\text { - Identify the best potential partner in India that already provided a complementary technology to the } \\
\text { Indian market } \\
\text { - Be able to get financial and business historical data of the potential Indian partner. The Swiss firm } \\
\text { should analyse very carefully the reputation of the Indian partner before doing the technology transfer } \\
\text { - Involve from the beginning a very skilled lawyer that understands both Swiss and Indian regulations } \\
\text { for technology transfer to enable a complete and successful technology transfer process following all } \\
\text { term and regulations } \\
\text { - It is important to define a common Swiss-Indo strategy for the products to be sold in India by the } \\
\text { Indian partner based on the Swiss technology } \\
\text { - The technology transfer process requires a detailed plan to transfer the license and product with very } \\
\text { clear and defined steps }\end{array}$} \\
\hline
\end{tabular}

Table 6. Technology Transfer to firm in Emerging Market identified benefits, risks and Critical Success Factors (CSF).

\subsection{Scenario 7: New services partnerships}

In this last identified scenario a Swiss company identifies an local firm(s) or organisation(s) that can support delivering new value added services in that particular emerging market. During the research project, both interviewed Indian and Swiss firms, mentioned that this trend is growing. For instance Japanese firms from the machine tool sector are currently developing service partnerships for 
product design and after sales service, especially because they don't count with the required workforce to provide these services locally.

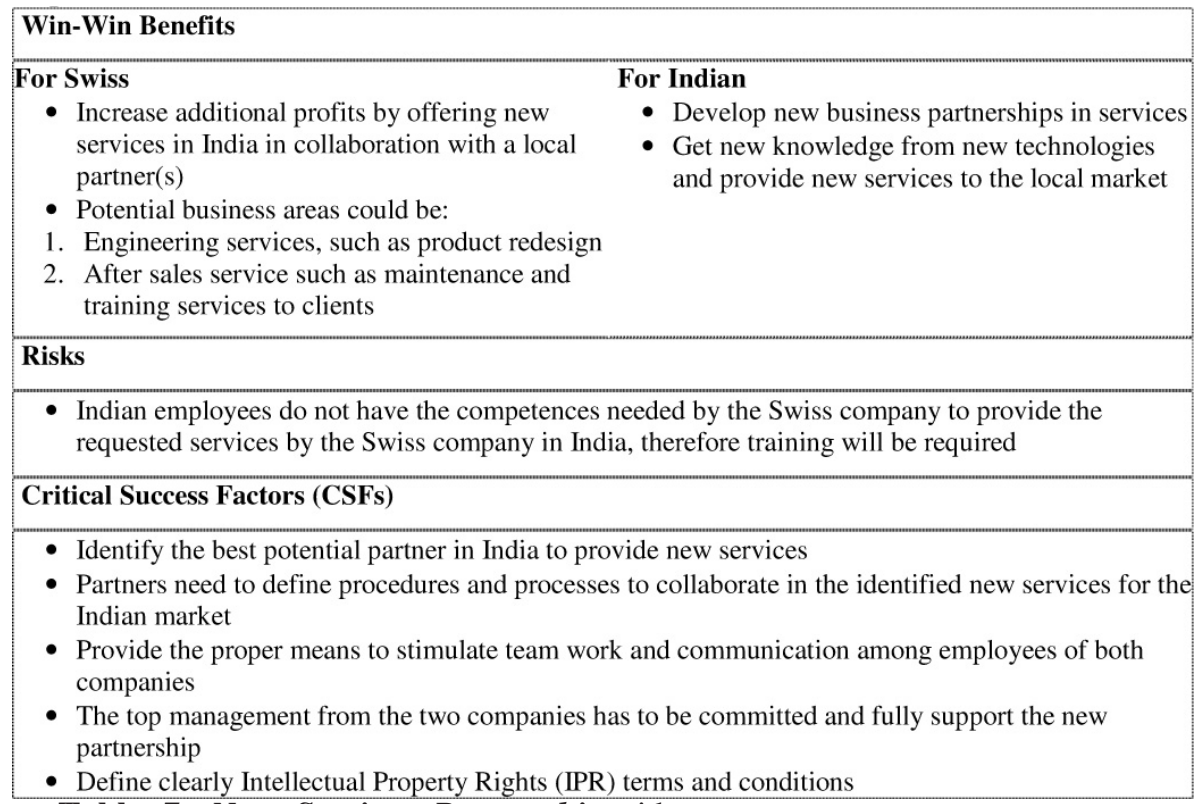

Table 7. New Services Partnerships identified benefits, risks and Critical Success Factors (CSF).

\section{CONCLUSIONS}

Based on the Scenario Planning methodology carried out during the SWISSMAIN Indian pilot, this paper has provided and insight to different possible scenarios that Swiss companies or other western companies could take into consideration to identify new business opportunities in emerging markets, focusing on India. The scenarios targeted the opportunity identification and risks that both Swiss and Indian partners may encounter. These seven scenarios were developed thanks to the different inputs provided by Swiss (located both in Switzerland and India) and Indian companies, giving highlights of the current business environment in India and sharing information about current risks and opportunities when collaborating with new partners within an Indian context. It should be remarked that despite the opportunities provided by highly collaborative scenarios, most of the times Swiss companies focused on full ownership models. This implies that up to now, the perceived risks are greater than the perceived opportunities to form new types of collaborations. For this reason, a particular attention should be devoted to the development of risk management approaches and a further comprehensive study on each scenario to classify and quantify in more detail the potential risks. This could enable to fully deploy the benefits of an open innovation approach. An interesting perspective is to focus on the last scenario, new services partnerships, because depending on the type of services this can be a favourable arena to develop collaborative practices without incurring in great risks where additionally the investment required is not too high. In every scenario it is important to consider that 
a common element for success is to define a new shared strategy and business model, where both counterparts look forward to work under an open collaborative framework to obtain win-win benefits implementing in the analysis a sustainable development framework (economical, social, environmental).

\section{ACKNOWLEDGEMENTS}

The authors would like to thank the Swiss Innovation Promotion Agency - CTI International for the funding provided to realise the SWISSMAIN Indian Pilot. Gratitude is also given to Mr. Duruz from Maillefer and Mr. Voirol from Bosch-Sapal, industrial partners of the SWISSMAIN project, who provided their business requirements to develop the scenarios. We also sincerely thank Prof. L.S. Ganesh, Prof. Srinivasan and Prof. Prakash Sai, from the Indian Institute of Technology in Madras for supporting this IndoSwiss research project and the 15 Swiss and Indian firms and organisations, which participated actively in the project during the face to face interviews. A special thank you note is also given to Prof. Dr. Claudio Boër, from the University of Applied Sciences of Southern Switzerland (SUPSI), for his important advises while Myrna Flores lead the SWISSMAIN Indian Pilot while working at the CIM Institute for Sustainable Innovation (ICIMSI) and last but not least to Michel Pouly from the Swiss Federal Institute of Technology, Lausanne (EPFL), the project leader of the SWISSMAIN project who invited and supported Myrna Flores as a visiting researcher in EPFL to develop this research during the summer of 2007 in Lausanne.

\section{REFERENCES}

Charter M. and Clark T., 2007, Sustainable Innovation Key conclusions from Sustainable Innovation Conferences 2003-2006, The Centre for Sustainable Design University College for the Creative Arts, www.cfsd.org.uk

Doz Y.L. and Hamel G., 1998, "The Alliance Advantage: The Art of Creating Value through Partnering" Harvard Business School Press, Boston, MA.

Dyer J H, Kale P and Singh H, 2001, “How to make Strategic Alliances Work” MIT Sloan Management Review 2001 Summer Pages 37-43

Dyer, J. H., 1996, "Specialized supplier networks as a source of competitive advantage-evidence from the Auto Industry", Strategic Management Journal 17(4), pp. 271-292.

Flores M., Boer C., Canetta L., Pouly M., Cherian M., 2008, "Critical Success Factors and Challenges to develop new Sustainable Supply Chains in India based on Swiss Experiences", To be published in the International Conference of Concurrent Enterprising, ICE Conference Proceedings 2008

Friedman T., 2005, The World is Flat, Penguin Ed.

Fung V., Fung W., Wind Y., 2000, Competing in a Flat World, Building Enterprises for a Borderless World, Wharton School Publishing, Pearson Power.

Larson A., 2000, Sustainable Innovation through an Entrepreneurship Lens, Business Strategy and the Environment 9: 304-317

Lorange, P and Roos, J (1992) "Strategic Alliance Formation, Implementation and Evolution”, Blackwell, Oxford.

India Economic data: http://india.gov.in/business/industry_services/small_medium_enterprises.php

Rennings K., 2000, Redefining Innovation - Eco-Innovation Research and the Contribution from Ecological Economics, Ecological Economics 32, 319 - 332

Schoemaker, P., 1995, Scenario Planning: A Tool for Strategic Thinking, Sloan Management Review; Winter 1995; 36, 2.

SCOR, 1995, Supply Chain Operations Reference Model, www.supply-chain.org

Subramanian, M.H. Bala, 2007, "Development strategies for Indian SMEs: promoting linkages with global transnational corporations" Management Research News; Volume: 30 Issue: 10.

Turner S., 2002, Tools for Success, A Manager's Guide. McGraw Hill.

Observatory of European SMEs, 2002, Regional clusters in Europe, European Community, http://europa.eu.int/comm/enterprise.

Porter M., 1990, The Competitive Advantage of Nations. Free Press, New York. 